\title{
PERBANDINGAN KONSEP PEMILIHAN JABATAN PUBLIK BPK ATAU SAI DI BEBERAPA NEGARA UNTUK MEWUJUDKAN BPK YANG INDEPENDEN
}

\author{
(Comparison of Appointment Concepts of the Supreme Audit Institution members \\ in Some Countries in Order to Create Independent BPK)
}

\author{
Widhya Mahendra Putra \\ Pascasarjana Fakultas Hukum Universitas Indonesia \\ Jalan Prof. Mr Djokosoetono, Pondok Cina, Beji, Kota Depok, Jawa Barat 16424 \\ Telp. 0217863443 \\ widhi.mahendra@gmail.com
}

Tulisan Diterima: 13 Februari 2019; Direvisi: 30 Mei 2019; Disetujui Diterbitkan 13 Juni 2019

DOI: http://dx.doi.org/10.30641/dejure.2019.V19.385-403

\begin{abstract}
According to laws and regulations, the members of the Supreme Audit Board (BPK) are appointed by the House of Representatives (DPR), by taking into account the opinions of the Regional Representative Council (DPD), which in this case is represented by its Consultative Board. However, the regulation of Article $23 E$ clause (1) of the Constitution of the Republic of Indonesia provides for that the BPK must be an independent state institution. The sole involvement of the House of Representatives as a legislative body in the appointment of the BPK leaders has been considered as burdened with political interests and that may influence the independence of the BPK. This research studies the appropriate DPR's powers in the appointment process of public officials of state institutions and comparing the appointment process of the leaders of the Indonesian supreme audit institution (BPK) in 20 countries. This research is conducted using a juridical-normative method by referring to the laws and regulations applicable in Indonesia as well as the constitutions of comparable countries. The analysis of this paper has a comparative scope related to the appointment concepts of the BPK leaders and the involvement of state's high institutions in appointment process of BPK leaders. The results indicate that appointment process of the BPK leaders should involve more than one state institution in order to maintain the principle of checks and balances among the institutions and at the same time the independence of the audit institution. This paper is expected to serve as a feedback for the policy makers in the appointment process of the leaders of the Indonesian Supreme Audit Board in the future.
\end{abstract}

Keywords: DPR; BPK leaders; independence; comparison of supreme audit institution.

\begin{abstract}
ABSTRAK
Menurut peraturan perundang-undangan, pemilihan anggota Badan Pemeriksa Keuangan (BPK) dilakukan oleh DPR dengan memperhatikan pandangan DPD yang dalam hal ini dilakukan oleh Badan Musyawarah. Sementara itu, pengaturan di dalam Pasal 23E ayat (1) Undang-Undang Dasar Negara Republik Indonesia menegaskan bahwa BPK harus menjadi lembaga negara yang mandiri. Keterlibatan DPR sebagai lembaga legislatif yang secara tunggal menentukan pimpinan BPK, dinilai sarat akan kepentingan politis dan mempengaruhi independensi atau kemandirian BPK. Studi ini meneliti bagaimana kewenangan DPR yang seharusnya dalam proses pemilihan pejabat publik lembaga negara dan membandingkan proses pemilihan pimpinan supreme audit institution (BPK) di 20 negara. Penelitian ini dilakukan melalui metode yuridisnormatif dengan mengacu pada hukum dan peraturan di Indonesia dan konstitusi negara-negara yang diperbandingkan. Analisis makalah ini memiliki ruang lingkup perbandingan terkait dengan konsep pemilihan pimpinan BPK dan keterlibatan lembaga-lembaga tinggi negara dalam pemilihan pimpinan BPK tersebut. Hasil dari perbandingan menunjukkan, pemilihan pimpinan BPK memerlukan lebih dari satu lembaga negara untuk menjalankan prinsip check and balances antar lembaga dan menjaga kemandirian lembaga audit suatu
\end{abstract}


negara. Tulisan ini diharapkan dapat memberikan masukan bagi pembuat kebijakan dalam menunjuk pimpinan Badan Pemeriksa Keuangan di Indonesia di masa depan.

Kata Kunci: DPR; pimpinan BPK; kemandirian; perbandingan supreme audit institution.

\section{PENDAHULUAN}

Keuangan negara merupakan salah satu unsur pokok dalam penyelenggaraan kehidupan suatu negara yang pemanfaatan dan pengelolaanya akan sangat mempengaruhi kemampuan negara dalam mewujudkan masyarakat yang adil, makmur dan sejahtera sebagaimana dicita-citakan dalam Pembukaan UUD NRI Tahun 1945. Berangkat dari kesadaran pentingnya pemanfaatan dan pengelolaan keuangan negara demi mewujudkan kesejahteraan rakyat, para pembentuk undang-undang dasar menghendaki agar dibentuk suatu lembaga yang berwenang memeriksa tanggung jawab keuangan negara. Salah satunya adalah Supomo yang dalam rapat besar BPUPKI tanggal 15 Juli 1945 menyampaikan bahwa:

"Untuk memeriksa tanggung-djawab tentang keuangan negara diadakan satu badan pemeriksa keuangan yang dulu dinamakan Rekenkamer, yang peraturannya ditetapkan dengan undang-undang. Itulah garis-garis besar tentang kekuasaan negara". ${ }^{1}$

Selanjutnya diaturlah Badan Pemeriksa Keuangan dalam Pasal 23 ayat (5) Undang-Undang Dasar Negara Republik Indonesia (UUD NRI Tahun 1945) dengan rumusan menyerupai usul Supomo, yaitu:

"Untuk memeriksa tanggung jawab tentang keuangan Negara diadakan suatu Badan Pemeriksa Keuangan, yang peraturannya ditetapkan dengan undang-undang. Hasil pemeriksaan itu diberitahukan kepada Dewan Perwakilan Rakyat."

Mengenai kedudukan Badan Pemeriksa Keuangan, Penjelasan Pasal 23 ayat (5) menerangkan bahwa:

"Cara pemerintah mempergunakan uang yang sudah dikeluarkan oleh DPR harus sepadan dengan keputusan. Untuk memeriksa tanggung jawab pemerintah itu perlu ada badan yang terlepas dari pengaruh dan kekuatan pemerintah. "Sebab itu badan dan kewajiban badan itu ditetapkan dengan undang-undang."

Rumusan yang demikian tersebut, menurut Jimly Asshiddiqie membawa konsekuensi bahwa BPK memiliki kedudukan tidak di atas pemerintah, tetapi juga tidak di bawah pengaruh pemerintah. BPK bersifat otonom atau independen dengan kedudukan yang sederajat dengan Presiden, DPR, Mahkamah Agung, dan seterusnya. Sebagai badan pemeriksa atau auditor, lembaga ini dapat digunakan sebagai instrumen yang digunakan untuk menentukan sendiri nasibnya melalui penentuan dan persetujuan APBN yang diberikan APBN sebagai acuan atau rujukan bagi Pemerintah untuk bekerja. ${ }^{2}$

Pengaturan BPK kemudian mengalami penyempurnaan pada saat dilakukannya amandemen ke IV terhadap UUD NRI Tahun 1945. BPK diatur dalam BAB VIIIA. Kemandirian dan kebebasan BPK yang dalam UUD NRI Tahun 1945 diletakkan pada penjelasan, dijadikan materi muatan dalam batang tubuh, dengan rumusan dalam Pasal 23E ayat (1) yaitu untuk memeriksa pengelolaan dan tanggung jawab tentang keuangan negara diadakan satu Badan Pemeriksa Keuangan yang bebas dan mandiri. Undang-Undang Dasar hanya bersifat menegaskan bahwa BPK haruslah menjadi sebuah lembaga yang mandiri, namun demikian bagaimana mengkonstruksi kelembagaan BPK agar dapat menjadi lembaga yang mandiri oleh UUD NRI Tahun 1945 diserahkan kepada pemerintah untuk menyusunnya dalam suatu undang-undang. Pada umumnya pola menyerahkan kewenangan mengatur kelembagaan agar dapat menjadi lembaga yang mandiri/independen ini juga digunakan pada lembaga lain seperti Bank Sentral. Kondisi yang demikian tentunya berpotensi melahirkan pengaturan yang di dalamnya membuka peluang mereduksi independensi/kemandirian lembaga.

Dalam konteks BPK, pelaksanaan kemandirian yang dicita-citakan oleh UUD NRI

\footnotetext{
${ }^{1}$ Jimly Asshidiqie, Konstitusi Ekonomi (Jakarta:

Kompas, 2010).
} 
Tahun 1945 akan sangat dipengaruhi banyak faktor, salah satunya dari mekanisme pengisian jabatan anggota BPK. UU Nomor 17 Tahun 2014 tentang MPR, DPR dan DPD dan Peraturan DPR Nomor 1 Tahun 2014 tentang Tata Tertib. Menurut dua peraturan tersebut, pemilihan anggota BPK dilakukan oleh DPR dengan memperhatikan pandangan DPD (Pasal 191) ${ }^{3}$, dan Pasal 207 Peraturan DPR Nomor 1 Tahun 2014 tentang Tata Tertib yang dalam hal ini dilaksanakan oleh Badan Musyawarah.

Konsep pemilihan ini sangat berbeda dengan mekanisme pemilihan gubernur yang diterapkan pada Bank Indonesia yang oleh UUD NRI Tahun 1945 juga diatur sebagai lembaga independen. Pada pemilihan Gubernur Bank Indonesia, pengusulan calon gubernur berasal dari Presiden namun persetujuan atas calon yang diusulkan tersebut datang dari DPR (Pasal 41) ${ }^{4}$. Dengan demikian tidak terdapat satu lembaga yang dominan kewenangannya dalam penentuan Gubernur Bank Indonesia.

Perbandingan mekanisme pemilihan pimpinan juga dapat kita lihat dari KPK. Dalam Sistem ketatanegaraan Indonesia, KPK bukan merupakan lembaga utama (main state organs, principal state organs) tetapi lembaga penunjang (state auxiliary organs). Pernyataan KPK sebagai lembaga yang bersifat independen dan bebas dari pengaruh kekuasaan manapun diatur dalam Pasal 3 UU Nomor 30 Tahun 2002 Tentang Komisi Pemberantasan Korupsi, yang berbunyi:

"Komisi Pemberantasan Korupsi adalah lembaga negara yang dalam melaksanakan tugas dan wewenangnya bersifat independen dan bebas dari pengaruh kekuasaan manapun."

Sebagai lembaga yang juga mandiri, yang kedudukannya bahkan bukan sebagai organ utama Negara, mekanisme pemilihan pimpinan KPK dibuat dengan sangat terbuka dan melibatkan lebih dari 1 (satu) lembaga. Hal ini dapat dilihat pada Pasal 30 ayat (1) yang mengatur bahwa pimpinan KPK di pilih oleh DPR dengan calon yang diusulkan dari Presiden. Selanjutnya dalam Pasal 30

\footnotetext{
${ }^{3}$ Undang-Undang No. 17 Tentang MPR, DPR, Dan DPD Tahun 2014, n.d.

${ }^{4}$ Undang-Undang No. 23 Tahun 1999 Tentang Bank Indonesia, 1999.
}

ayat (2), untuk dapat menentukan calon pimpinan KPK yang diusulkan pemerintah, maka pemmerintah membentuk panitia seleksi.

Dari 2 undang-undang lain, terlihat jelas perbedaan mekanisme pengisian jabatan pada Bank Indonesia dan KPK dengan pengisian anggota BPK. UU BPK membuat mekanisme pemilihan yang memberi kedudukan dan peran sangat besar kepada DPR serta tidak diimbangi dengan mekanisme check and balances dari lembaga lain, kecuali DPD yang lingkup kewenangannya terbatas pada memberi pertimbangan. Walaupun dari sisi teori, konsepsi demikian dapat dimaklumi mengingat BPK adalah perpanjangan tangan dari fungsi pengawasan DPR. Namun, konsep mekanisme pengisian jabatan ini memiliki kelemahan. Bagi eksternal auditor yang menggunakan model board seperti BPK, metode pemilihan pimpinan dan anggota (dewan) disoroti sebagai salah satu titik lemah yang dapat mempengaruhi kemandirian eksternal auditor. Terutama jika terdapat satu partai politik yang dominan. Hal ini sebagaimana ditegaskan:

"in cases where one political party has a
dominant position in Parliament, it may
exercise excessive influence over who is
appointed to the Board of the SAI, thus
reducing the independence and objectivity of
the SAI in carrying out its work."

Kekhawatiran ini sebenarnya relevan dengan kondisi BPK kedepannya, melihat performa anggota DPR yang condong membela kepentingan politiknya sehingga membuka potensi tekanan kepada pimpinan/dewan dalam hal terjadi persimpangan dengan kepentingan politik. Alasanalasan politis lebih mendominasi dari pada pertimbangan kompetensi dan integritas. ${ }^{5}$ Selain itu, performa DPR dalam memilih calon pimpinan BPK juga kurang optimal, sebagai contoh: kesalahan paling fatal DPR adalah meloloskan calon yang pernah tersangkut kasus korupsi. Telah jelas dan tegas dinyatakan dalam UU BPK bahwa mereka yang pernah dijatuhi pidana penjara karena melakukan tindak pidana yang diancam dengan hukuman 5 tahun atau lebih tidak boleh menjadi calon. $^{6}$

\footnotetext{
${ }^{5}$ Oce Madril, "Pemilihan Anggota Badan Pemeriksa Keuangan," Koran Tempo, 2013.

${ }^{6}$ Dumaria Simanjuntak, "Pengisian Jabatan Anggota Badan Pemeriksa Keuangan (BPK) Untuk Mewujudkan
} 
Salah satu fakta ini menunjukkan adanya permasalahan dalam mekanisme pemilihan yang dilaksanakan oleh DPR. Proses fit and proper test selama ini hanya sebagai ajang transaksi politik. Bahkan, tak jarang, proses itu menjadi ajang transaksi suap. ${ }^{7}$ Belum lagi berbagai kasus yang muncul pada pemilihan pejabat publik lainnya. Hasil seperti ini dapat terjadi karena DPR-lah yang memegang kendali mutlak dan tidak ada lembaga lain yang berfungsi sebagai penyeimbang atas keputusan DPR. Pertimbangan DPD terkait pemilihan pimpinan BPK tidak cukup kuat bahkan dapat diabaikan oleh DPR.

Kedudukan BPK secara teoritis mungkin tidak berada dalam suatu "relasi hierarkis" dalam bentuk apapun dengan DPR/lembaga lain namun ada relasi antara anggota BPK yang dipilih dengan DPR yang dapat berpotensi menjadi titik lemah sebagaimana telah diuraikan sebelumnya. Oleh karena itu, perlu kiranya mencari formula pengisian pimpinan BPK yang dapat membantu mewujudkan BPK yang mandiri dan bebas sebagaimana dicitacitakan oleh UUD NRI Tahun 1945 dengan mencari perbandingan pengaturan BPK atau yang dalam terminologi bahasa asing disebut sebagai supreme audit institusion untuk memecahkan masalah pengisian jabatan yang bersifat tertutup ini.

Atas dasar perbagai permasalahan yang dijabarkan pada latar belakang, maka penelitian ini hendak menganalisis mekanisme check and balances dan dominasi kekuasaan DPR dalam proses pemilihan pimpinan BPK dengan membandingkan proses yang sama di berbagai Negara. Untuk itu, pokok permasalahan dari penelitian ini berfokus pada dua hal. Pertama, bagaimana perbandingan konsep pemilihan pimpinan jabatan publik BPK dan/atau Supreme Audit Institution (SAI) di Beberapa Negara? Kedua, bagaimana konsep pemilihan pimpinan BPK yang paling tepat dikaitkan dengan hasil perbandingan dalam rangka mewujudkan BPK yang bebas dan mandiri?

BPK Yang Independen," Jurnal Hukum dan Pembangunan Tahun ke 4747 No. 2 (2017).

\footnotetext{
${ }^{7}$ Mochamad Taufik Riyadi, "Peninjauan Ulang Kewenangan DPR Dalam Seleksi Pengisian Jabatan Publik,” 2015.

${ }^{8}$ Soerjono Soekanto, Pengantar Penelitian Hukum, Cetakan.3. (Jakarta: UI Press, 1986).
}

\section{METODE PENELITIAN}

Dalam penelitian ini, bentuk penelitian yang akan disajikan adalah penelitian yuridis normatif atau penelitian hukum normatif, yaitu dengan menganalisis sebuah kebijakan dari sisi hukum untuk memahami kondisi intrinsik aturan hukum. Penelitian hukum normatif sepenuhnya menggunakan data sekunder, penyusunan kerangka konsepsionil diperlukan untuk mempergunakan perumusan-perumusan yang terdapat di dalam peraturan perundang-undangan yang dijadikan dasar penelitian. ${ }^{8}$ Objek penelitian ini adalah mekanisme pengisian jabatan pimpinan BPK oleh DPR, yang dilihat dari perspektif komparasi atau perbandingan dari konsep pemilihan pimpinan supreme audit institution dan kaitannya untuk mewujudkan lembaga audit negara yang bebas dan mandiri. Penelitian ini menggunakan pendekatan perbandingan norma dasar atau konstitusi, Pendekatan norma dasar atau konstitusi digunakan untuk mengetahui pengisian pimpinan supreme audit institution di beberapa negara.

Sementara itu, pendekatan komparatif digunakan dengan membandingkan pelaksanaan mekanisme pemilihan pimpinan supreme audit institution di dua puluh negara. Kegunaan dari penerapan perbandingan hukum adalah, antara lain, bahwa penelitian tersebut akan memberikan pengetahuan tentang persamaan dan perbedaan antara perbagai bidang tata hukum dan dasar sistem hukum, dengan pengetahuan tersebut maka akan mudah untuk mengadakan unifikasi, kepastian hukum, maupun penyederhanaan hukum. ${ }^{9}$ Ditinjau dari segi bentuknya, penelitian ini diarahkan sebagai penelitian evaluatif dengan maksud menilai materi muatan dalam peraturan perundangundangan yang terkait dengan kewenangan DPR dalam pemilihan pimpinan BPK. ${ }^{10}$ Sedangkan, jenis data yang digunakan dalam penelitian ini adalah data sekunder yang berasal dari bahan hukum primer dan bahan hukum sekunder. Bahan hukum

\footnotetext{
${ }^{9}$ Ibid.

${ }^{10}$ Lailani Sungkar Mei Susanto, Rahayu

Prasetianingsih, "Kekuasaan DPR Dalam Pengisian

Pejabat Negara Dalam Sistem Ketatanegaraan

Indonesia," Jurnal De jure Kemenkumham 18 Nomor 1 (2018).
} 


\section{(1) Akreditasi: Kep. Dirjen. Penguatan Risbang. Kemenristekdikti:}

primer dalam penelitian ini adalah UUD Negara RI Tahun 1945, peraturan perundang-undangan, dan konstitusi negara-negara yang diperbandingkan. Untuk bahan hukum sekunder, akan digunakan bahan-bahan berupa macam-macam buku dan karya tulis ilmiah lainnya yang berhubungan dengan kewenangan DPR dalam pemilihan pimpinan BPK.

Hasil penelitian diharapkan akan bersifat evalutif dan perskriptif analitis. Hasil perbandingan dari beberapa negara mengenai mekanisme pemilihan pimpinan BPK atau SAI akan digunakan untuk menganalisis dan mengevaluasi pemilihan pimpinan BPK, parameter yang digunakan untuk melakukan analisis yakni bentuk SAI dari negaranegara bersangkutan dan peringkat SAI dari negaranegara yang diperbandingkan. Pada akhirnya, hasil perbandingan diharapkan akan menunjukkan masukan bagi mekanisme pemilihan pimpinan BPK di Indonesia untuk mewujudkan BPK yang independen.

\section{PEMBAHASAN DAN ANALISIS}

\section{A. Perbandingan Konsep Pemilihan Pimpinan Jabatan Publik BPK dan/atau Supreme Audit Institution (SAI) di Beberapa Negara}

Pengaturan mengenai Badan Pemeriksa Keuangan diatur dalam Undang-undang Nomor 15 Tahun 2006 tentang Badan Pemeriksa Keuangan. Selanjutnya terkait dengan BPK sebagai lembaga negara yang independen, di pasal 2 UU No. 15 Tahun 2006 disebutkan bahwa BPK merupakan satu lembaga negara yang bebas dan mandiri dalam memeriksa pengelolaan dan tanggung jawab keuangan negara. Bebas diartikan dapat melakukan segala tindakan yang terkait pengelolaan dan tanggung jawab keuangan negara dengan tidak melanggar ketentuan peraturan perundangundangan yang berlaku. Sementara itu, mandiri diartikan dalam melakukan pemeriksaan atas pengelolaan dan tanggung jawab keuangan negara tidak boleh dipengaruhi oleh siapapun termasuk pihak eksekutif, legislatif, yudikatif dan dari dalam Badan Pemeriksa Keuangan sendiri. ${ }^{11}$

11 “Badan Pemeriksa Keuangan," last modified 2018, http://e-journal.uajy.ac.id/6942/3/ MIH201802.pdf, akses 3 Mei 2018.
Dalam konteks internasional, lembagalembaga negara seperti BPK yang menjalankan fungsi atau bertanggung jawab terhadap audit pendapatan dan pengeluaran pemerintah disebut dengan istilah Supreme audit institution. Hal ini sebagaimana disampaikan oleh World Bank, yaitu:

Supreme audit institutions are national
agencies responsible for auditing govern-
ment revenue and spending. Their legal
mandates, reporting relationships, and
effectiveness vary, reflecting different gov-
ernance systems and government policies.
But their primary purpose is to oversee the
management of public funds and the qual-
ity and credibility of governments' reported
financial data. ${ }^{12}$

Keberadaan supreme audit institution dalam konteks internasional didasari pentingnya akuntabilitas fungsi keuangan suatu negara, sesuai dengan pernyataan,

"Accountability is a cornerstone for the functioning of states and therefore not only shapes the work of Supreme audit institutions (SAIs) but also the work of general government and the citizens' trust in governmental compliance". ${ }^{13}$

Diantara beberapa hal yang menjadi lingkup kewenangan SAIs antara lain dijabarkan sebagai berikut,

"The SAIs provide assurance as to whether the executive branch complies with these rules and responsibilities and highlight infringements of the rules; The SAIs thereby contribute to strengthening accountability and improving government operations; By acting transparently and credibly the SAIs can further enhance the value of their contribution; Institutional and financial independence of the SAIs is an indispensable prerequisite for enabling them to successfully perform their audit function". ${ }^{14}$

SAI sebagai lembaga audit memberikan jaminan atas kegiatan cabang eksekutif sesuai

12 World Bank, "Features and Functions of Supreme

Audit Institutions,” Premnotes Public Sector 59 (2001).

${ }^{13}$ Ibid.

14 Ibid. 
aturan dan tanggungjawabnya atau tidak, SAIs berkontribusi memperkuat akuntabilitas dan meningkatkan operasi pemerintah. Bergerak secara transparan dan kredibel guna meningkatkan kinerja dan kontribusi institusi. Selain itu, kelembagaan dan kemandirian finansial dari SAI adalah prasyarat yang sangat diperlukan untuk memungkinkan mereka untuk berhasil dalam melaksanakan fungsi auditnya.

Dalam teori mengenai lembaga-lembaga negara terkadang dikenal istilah independent bodies, yakni suatu perangkat organ negara yang independen (bebas dan mandiri) dalam artian dalam menjalankan tugasnya tidak diintervensi oleh lembaga/organ negara lainnya. Pengertian dasar dari istilah "independent" adalah adanya kebebasan, kemerdekaan, kemandirian, otonom (otonomi), tidak dalam dominasi personal maupun institusional. Sehingga, ada pelaksanaan kehendak bebas (free will) yang dapat terwujud tanpa ada pengaruh yang secara signifikan merubah pendiriannya untuk membuat keputusan atau kebijakan. Secara filosofis, person atau institusi yang independen (otonom) dibatasi oleh tujuantujuan mulia yang ditetapkan sendiri atau ditetapkan oleh otoritas yang lebih tinggi (Iebih berwenang) yang dalam operasional selanjutnya tidak lagi dapat mencampuri pelaksanaan fungsinya yang independen. ${ }^{15}$ Terkait dengan Lembaga atau institusi negara yang independen berarti tidak ada suatu apapun yang dapat melakukan intervensi atau mengikatnya dalam mengambil sikap atau kebijakan yang diprediksi dapat membawa kemaslahatan bagi tujuan yang sudah ditetapkan. ${ }^{16}$ Keberadaan lembaga independen ini pada dasarnya untuk membatasi kekuasaan lembaga eksekutif dan sebagai bentuk memperkuat check and balances antar lembaga.

Dalam kaitannya untuk mewujudkan SAI yang bebas dan mandiri (independen) langkah awal yang harus dilakukan oleh suatu negara adalah menjamin bahwa dalam pemilihan pimpinan SAI bebas dari pengaruh atau intervensi politik atau kekuasaan tertentu dalam suatu negara. Hal tersebut dapat dilakukan dengan menjalankan mekanisme check and balances antar Lembaga negara yang terlibat dalam pemilihan pimpinan SAI. Untuk

\footnotetext{
${ }^{15}$ Hendra Nurtjahjo, Lembaga, Badan, Dan Komisi Negara Independen (State Auxiliary Agencies) Di Indonesia: Tinjauan Hukum Tata Negara (Jakarta, 2005).
}

melihat bagaimana kecenderungan mekanisme pemilihan pimpinan/anggota/dewan Supreme audit institution dalam rangka mewujudkan kelembagaan SAI yang mandiri. Berikut diperbandingkan mengenai mekanisme pemilihan pimpinan/anggota/dewan SAI pada 20 negara.

\section{1) Amerika Serikat}

Supreme audit institution Amerika Serikat disebut dengan Goverment Accountability Office (disingkat) GAO. GAO adalah lembaga negara yang menyediakan jasa audit, evaluasi, dan investigasi untuk Kongres Amerika Serikat. GAO merupakan bagian dari cabang kekuasaan legislatif. GAO dipimpin oleh seorang "comptroller general". Tata cara pemilihan dan pengangkatan comptroller general tidak diatur dalam konstitusi melainkan dalam GAO act tahun 1980. Dalam section 104 diatur bahwa, ketika terjadi kekosongan jabatan pada kantor "comptroller general" atau pada kantor deputi of comptroller general maka akan dibentuk komisi untuk merekomendasikan individu kepada Presiden untuk pengangkatan pejabat pada posisi yang kosong tersebut.

Komisi ini akan mengusulkan kepada Presiden sebagai bahan pertimbangan paling sedikit 3 (tiga) nama untuk mengisi posisi dimaksud. Namun Presiden dengan diskresinya, dimungkinkan untuk meminta nama tambahan kepada komisi dimaksud. Presiden selanjutnya akan memilih satu nama untuk mengisi posisi yang kosong tersebut. Hasil pemilihan oleh presiden harus dikonfirmasi oleh senat.

2) Belanda

Supreme audit institution Belanda disebut The General Chamber of Audit yang diatur dalam BAB IV Konstitusi Belanda tentang Council Of the State, Chamber of Audit and Advisory Bodies. Pada Pasal 76 tentang General Chamber of Audit diatur bahwa The General Chamber of Audit bertanggung jawab untuk memeriksa pendapatan dan pengeluaran negara. Selanjutnya dalam Pasal 77 diatur bahwa anggota The General Chamber of Audit akan diangkat dengan Keputusan Kerajaan

16 Ibid. 
dengan mendasarkan pada tiga usulan nama yang dibuat oleh the lower Chamber of the Parliament atau yang disebut dengan tweede kamer atau dalam istilah inggrisnya disebut dengan house of representative.

Kemudian dalam Pasal 2 angka 1 National Ordinance on the General Audit Chamber diatur bahwa The General Audit Chamber shall consist of three members including the chairman. ${ }^{17}$ Hal ini bermakna anggota The General Audit Chamber sebagai mana dimaksud dalam konstitusi Belanda terdiri dari 3 orang yang termasuk didalamnya pimpinan The General Chamber of Audit. Mekanisme pemilihan diatur dalam Pasal 2 angka 3 National Ordinance yang menyatakan bahwa The Parliament will propose two individuals to the Governor for each appointment. Berdasarkan ketentuan ini maka untuk mengisi posisi anggota dimaksud, Parlemen akan mengusulkan 2 nama untuk setiap posisi dimaksud dan diajukan kepada Gubernur untuk ditunjuk. Adapun 2 nama tersebut, menurut ketentuan Pasal 2 angka 4 dipilih dari 3 usulan nama dari The General Chamber of Audit yang telah disetujui oleh mayoritas suara. Untuk selanjutnya diserahkan kepada Governor untuk diputuskan. Hasil inilah nantinya yang akan diangkat dengan keputusan kerajaan. Agar dapat ditunjuk, setiap individu harus memenuhi persyaratan yaitu memiliki kewarganegaraan Belanda dan menjadi penduduk Sint Maarten sebagaimana diatur dalam Pasal 3 angka 1.

3) Brasil

Supreme audit institution Brazil, dalam konstitusi Brazil disebut dengan Audit Tribunal of the Union yang berbentuk pengadilan. Pengaturan Audit Tribunal of The Union terdapat dalam Bagian IX tentang Akuntansi, Keuangan dan Pengawasan Keuangan yang masuk dalam ruang lingkup pengaturan Bab I tentang Kekuasaan Legislastif.Konstruksi rumusan yang demikian menunjukkan bahwa pada dasarnya kedudukan audit tribunal secara kelembagaan lebih condong sebagai bagian dari kekuasaan legislatif karena tugasnya adalah membantu

\footnotetext{
17 "No Title,"
}

http://www.arsxm.org/EN/About/Organization/Docume nts/LandsverordeningAlgemeneRekenkamer_EN_final_ salah satu fungsi dari kongres yaitu pengawasan keuangan.Dalam menjalankan tugas dimaksud, audit tribunal memiliki 9 (sembilan) orang hakim yang berkedudukan di federal distrik, memiliki staf sendiri dan memiliki yurisdiksi diseluruh wilayah brasil.

Mekanisme pemilihan 9 (sembilan) hakim diatur dalam Pasal 73 ayat (2) tentang Audit Tribunal yang berbunyi:

\section{The Justices of the Audit Tribunal of the} Union are chosen as follows:

I. one third by the President of the Republic with the approval of the Federal Senate, two of them being alternately chosen among auditors and members of the Attorney General's Office at the Court, as indicated in a triple list by the Court, in accordance with criteria of seniority and merit;

II. two thirds by Congress.

Dengan demikian, pemilihan hakim pada audit tribunal Brazil tidak dilaksanakan hanya oleh kongres saja, melainkan juga mengikutsertakan cabang kekuasaan lain yakni Presiden Brazil. Presiden Brazil kewenangan memilih hakim dengan jumlah $1 / 3$ dari 9 hakim, yaitu 3 orang hakim dengan menda

pat persetujuan senat, sedangkan $2 / 3$ sisanya menjadi kewenangan Kongres.

4) Argentina

Konstitusi Argentina mengatur bahwa kontrol eksternal terhadap kekayaan negara, ekonomi dan keuangan serta aspek pelaksanaan lainnya merupakan kewenangan khusus dari kekuasaan legislatif. Hal ini sebagaimana diatur dalam Pasal 85 ayat (1) yang menyatakan "The Legislative Power is exclusively empowered to exercise the external control of the national civil service as regards its estates and its economic, financial and operative aspects. Pendapat legislatif ini didasarkan pada laporan dari The General Auditing Office of the Nation. The General Auditing office of the nation inilah yang disebut sebagai supreme audit institusion dari Argentina. The General Auditing Office of the

111111 comments JDM 201211.pdf, akses 12 November 2018 . 
Nation berkedudukan sebagai badan penasehat teknis dari kongres namun bersifat independen sebagaimana diatur dalam Pasal 85 ayat (3) yaitu "This technical advisory body of Congress with functional autonomy...".

The General Auditing Office of the Nation dipimpin oleh seorang chairman yang ditunjuk/diangkat dari usulan partai oposisi dengan jumlah anggota dewan terbanyak dalam kongres sebagaimana diatur dalam Pasal 75 ayat (3) yaitu "... The chairman of the body shall be appointed under the proposal of the Opposition with the largest number of legislators in Congress". Dalam konteks Argentina, kewenangan pemilihan chairman/pimpinan dari The General Auditing Office of the Nation sepenuhnya menjadi kewenangan dari kekuasaan legislatif.

5) Portugal

Lembaga yang memiliki kewenangan pengawasan terhadap pelaksanaan anggaran, dalam konstitusi Portugal, sebagaimana diatur dalam Pasal 110 tentang supervisi adalah The Court Audit dan the Assembly of the Republic. The Court of Audit inilah yang disebut sebagai supreme audit institutionnya negara Portugal. The Court Audit merupakan salah satu jenis pengadilan sebagaimana diatur dalam Pasal 211 Konstitusi Portugal. Adapun struktur organisasi dari the court Audit tidak diatur dalam konstitusi. Struktur organisasi diatur dalam Act 98/97 on Organisation and Procedural Law of the Court of Auditors sebagaimana telah diubah terakhir kali dengan Act 35/2007.

Dalam Bab III tentang Struktur dan Organisasi The Court of Audit, Section I tentang Struktur dan Organisasi, Pasal 14 bahwa The Court of Audit terdiri dari: 1) pada kantor pusat yaitu The President dan 16 hakim serta 2) pada negara bagian oleh seorang hakim. Selanjutnya dalam Pasal 16 diatur bahwa The President of the Court of Auditors is appointed in accordance with the terms of the Constitution. Menurut konstitusi Portugal maka kewenangan penunjukkan/pengangkatan Presiden the Court of Auditor merupakan kewenangan Presiden Republik Portugal dengan mendasarkan pada usul pemerintah/the Goverment sebagaimana diatur dalam Pasal 137 yaitu

\begin{abstract}
"Where other organs are concerned, the President of the Republic has the following powers : ...p) To appoint and relieve of their posts, at the proposal of the Government, the president of the Court of Audit and the AttorneyGeneral"
\end{abstract}

The Goverment sebagaimana dimaksud dalam Pasal 137 terdiri atas Perdana Menteri, para Menteri lainnya, dan Sekretaris Negara dan Wakil Sekretaris sebagaimana diatur dalam Pasal 186 yaitu The Government comprises the Prime Minister, the other Ministers, and the State Secretaries and Under-Secretaries. Selanjutnya dalam Pasal 137 ayat (2) diatur bahwa When a judge of the Court itself is appointed as President, his respective place remains captive during his mandate as President maka dapat disimpulkan bahwa Presiden of the court of audit ini dapat berasal dari hakim, dalam hal ia berasal dari hakim maka ia terikat ketentuan ayat (2) ini, namun tidak menutup kemungkinan berasal dari luar hakim.

\section{6) Afrika Selatan}

Kewenangan pengawasan terhadap anggaran, laporan dan manajemen keuangan bukan dilekatkan pada lembaga melainkan kepada auditor general. Konstitusi Afrika Selatan juga mengatur syarat untuk dapat menjadi auditor general sebagaimana diatur dalam Pasal 193 ayat (3) yaitu pria/wanita warga negara Afrika Selatan yang layak dan patut untuk menjalankan kantor. Selain syarat tersebut, memiliki pengetahuan khusus, atau pengalaman dalam, audit, keuangan negara dan administrasi publik juga menjadi bahan perhatian/pertimbangan dalam penunjukkan auditor general.

Adapun mekanisme penunjukkan melibatkan dua istitusi yaitu presiden dan National Assembly. Presiden yang melakukan penunjukkan Auditor General, sedangkan National Assembly memberi rekomendasi mengenai calon yang akan ditunjuk kepada presiden. Penunjukkan yang dilakukan oleh presiden akan mendasrkan pada rekomendasi dimaksud. Hal ini sebagaimana diatur dalam Pasal 193 ayat (4) yaitu The President, on the recommendation of the National Assembly, must appoint the Public Protector, the AuditorGeneral. Calon yang direkomendasikan oleh 
De Jure No: 10EEEPTI2019

national assembly untuk mengisi posisi auditor general adalah calon yang disetujui oleh National Assembly dengan suara pendukung paling sedikit 60 persen dari anggota the National Assembly sebagaimana diatur dalam ayat (5).

7) Korea Selatan

Korea Selatan dalam konstitusinya mengatur bahwa pengawasan dan pemeriksaan terhadap pendapatan dan pengeluaran Negara, termasuk di dalamnya kinerja lembaga eksekutif dan pejabat publik dilaksanakan oleh The Board of Audit and Inspection yang berada dibawah yurisdiksi Presiden Korea Selatan. Pimpinan The Board of Audit ditunjuk oleh Presiden dengan persetujuan dari National Assembly yang diatur dalam Pasal 98 ayat (2), sedangkan pada ayat (3) diatur bahwa untuk anggota lainnya diluar pimpinan ditunjuk oleh Presiden dengan berdasar pada rekomendasi dari pimpinan The Board of Audit. Keikutsertaan kekuasaan legislatif dalam pemilihan para anggota dewan The Board of Audit hanya berlaku untuk pemilihan pimpinan dan tidak pada peilihan anggota diluar pimpinan.

8) Singapura

Singapura termasuk dalam negara yang menggunakan model westmintser audit institusion. Oleh karena itu, yang diatur dalam konstitusi lebih menekankan kepada General Auditor selaku kepala supreme audit institusion di Republik Singapura di banding membahas mengenai kelembagaan/institusi auditnya. General Auditor inilah yang akan menjalankan/mengelola institusi audit Republik Singapura sebagaimana diatur dalam Pasal 148 ayat (5) yaitu "subject to the provisions of this article, the Auditor-General shall hold office...".

General Audit ditunjuk oleh Presiden sesuai dengan nasehat/masukan dari Perdana Menteri kecuali Presiden, yang bertindak sesuai kebijaksanaannya, tidak sependapat dengan saran itu yang diatur dalam Pasal 148 ayat (1) yaitu there shall be an Auditor-General who shall be appointed by the President in accordance with the advice of the Prime Minister unless the President, acting in his discretion, does not concur with that advice. Prime Minister sebelum memberi saran oleh konstitusi diperintahkan untuk berkonsultasi kepada Ketua Komisi Layanan Publik sebagaimana diatur dalam Pasal 148 ayat (2) yang menyatakan The Prime Minister shall, before tendering any advice under clause (1), consult the Chairman of the Public Service Commission.

9) Spanyol

Konstitusi Spanyol hanya mengatur mengenai kewenangan pengawasan terhadap keuangan dan dan manajemen ekonomi negara dan sektor publik yang dimiliki oleh The Court of Accounts. Konstitusi tidak mengatur mengenai anggota dari The Court of Accounts. Pengaturan lebih lanjut mengenai anggota termasuk mekanisme pemilihannya diatur dalam Law 2/1982 Organic Court of Audit.

The Court of Accounts memiliki 12 anggota/members yang termasuk didalamnya seorang presiden dan seorang penuntut umum. The President of The Court of Account ditunjuk diantara para anggota yang penujukkannya dilakukan oleh raja dengan mendasarkan pada usulan pengadilan sebagaimana diatur dalam Pasal 29 yang menyatakan The President of the Court of Accounts shall be appointed from among its members by the King, on the proposal of the same Court in plenary session and for a period of three years. Kandidat/calon anggota ini dapat berasal dari berbagai profesi antara lain akuntan, profesor dari universitas, pejabat publik pada kantor yang mensyaratkan kualifikasi akademik tinggi, pengacara dan latar belakang pekerjaan/pengalaman lain sebagaimana diatur dalam undang-undang ini. Adapun untuk pemilihan 12 anggota tersebut dilaksanakan oleh Parlemen, enam Kongres Deputi dan enam oleh Senat, dengan suara mayoritas tiga perlima dari masing-masing kamar.

10) Swedia

Konstitusi Swedia tidak mengatur secara spesifik Swedia National Audit Office. Konstitusi hanya mengatur bahwa untuk memeriksa kegiatan Negara, Parlemen akan akan memilih auditor dari antara anggotanya. Pengaturan lebih lanjut mengenai the auditors akan diatur lebih lanjut dalam peraturan/undang-undang parlemen. Sebagai tindak lanjut perintah konstitusi, dibentuklah Audit of Government Accounts etc. Act Consolidation of Consolidating Act No. 3 of 7 
January 1997 as amended by Act No. 590 of 13 June 2006 as amended by Act No. 1272 of 21 December 2011 yang mengatur mekanisme pemilihan auditor oleh parlemen. Dalam Audit of Government Accounts etc. Act dinyatakan bahwa audit terhadap keuangan pemerintah, institusi, asosiasi, yayasan yang pengeluarannya didanai/ditanggung oleh negara, dan berbagai audit lain yang diatur dalam Undang-Undang ini dilaksanakan oleh an Auditor General.

Pada Pasal 1 dinyatakan bahwa The audit according to this act shall be performed by an Auditor General appointed by the Speaker of the Folketing (Parliament) and approved by the Standing Orders Committee of the Folketing. Dalam penunjukkan auditor general, juga mengikutsertakan Pubic Account Comitte (PAC). PAC sebagaimana diatur dalam Pasal 1 ayat (3) harus menyampaikan rekomendasi kepada speaker of the Folketing, untuk selanjutnya akan diberikan oleh The Spekaer kepada the Standing Orders Committee setelah dikonsultasikan terlebih dahulu dengan deputy speaker. Dalam hal the speaker tidk menyetujui rekomendasi PAC, maka PAC harus menyampaikan rekomendasi baru. Keikutsertaan PAC dalam pemilihan auditor general hanya berlaku apabila auditor general diberhentikan sebelum masa jabatannya berakhir.

11) Filiphina

Filiphina dalam konstitusinya mengatur secara spesifik mengenai the comission on auditnya, pengaturan mengenai audit institution di Filiphina tersebut, khususnya mengenai pemilihan pimpinan/the chairman and the comissioner diatur dalam "the 1987 Constitution of The Republic of The Philippines" article $I X$ section 2 yang mengatur soal the commission on audit di filiphina.

Komisi audit di Filiphina terdiri dari seorang ketua dan dua komisaris yang diangkat oleh presiden dengan persetujuan dari "the comission on appointment" (komisi penunjukkan) dalam jangka waktu kepimpinan sebagai ketua selama 7 tahun dan sedangkan komisaris pertama selama 5 tahun dan komisaris lainnya selama tiga tahun tanpa reappointment (tidak ditunjuk lagi).
12) China

China mengatur mengenai audit institutionnya dalam "China (People's Republic of)'s Constitution of 1982 with Amendments through 2004". Di china organ negara yang menjalankan fungsi audit dipimpin oleh auditor general yang didirikan oleh The State Council, wewenangnya adalah mengaudit penerimaan dan belanja seluruh departemen dibawah state council, pemerintahan daerah, keuangan negara, organisasi perbankan, dan perusahaan.

Dalam pemilihan auditor general sebagai head of auditing body di china diatur pada article 62 mengenai head of government selection. Pemilihan jendral auditor sebagai kepala badan audit di China dilakukan oleh kongres China. Selain itu, Presiden RRC juga memiliki kewenangan untuk pengangkatan dan pemecatan jendral auditor yang didasarkan pada pada keputusan kongres China dan komitenya, sebagaimana disebutkan dalam article 80 .

13) Vietnam

Vietnam mengatur tentang Audit institutionnya melalui konstitusi "Final Constitution of the Republic of Vietnam Adopted by the National Assembly" yang diberi nama the state audit. Konstitusi vietnam mengatur mengenai pemilihan the head of state audit dalam article 70 poin 7 . Menurut pasal tersebut, the head of the state audit di vietnam dipilih dan diberhentikan oleh national assembly (majelis nasional/DPR) karena menurut konstitusi vietnam the state audit adalah organ yang dibuat oleh national assembly. The state audit bertindak independen dan mengikuti undang-undang.

14) Mesir

Mesir dalam konstitusinya "Egypt's Constitution of 2014", mengatur mengenai audit institution yang diberi nama Central Auditing Organization. Sebagai badan independen, central auditing organization dalam pemilihan pimpinan/ketuanya dilakukan oleh presiden dengan persetujuan house of representatives yang tertuang dalam article 216 mengenai Creation of each independent body or regulatory agency. 


\section{5) Kenya}

The Constitution of Kenya, 2010 mengatur state organ atau organ negara yang melakukan audit yaitu auditor general sebagai head of audit institution di Kenya. Sementara itu, untuk kantor-kantor auditor general akan diaudit dan dilaporkan oleh akuntan profesional yang ditunjuk oleh national assembly (DPR). Pemilihan auditor general disebutkan dalam article 229. Menurut article/pasal tersebut, jenderal auditor diajukan oleh presiden untuk disetujui oleh DPR dan ditunjuk atau diangkat oleh Presiden. Selain itu pada ayat berikutnya di article/pasal yang sama, diatur masa kepemimpinan dari auditor selama 8 tahun tanpa boleh ditunjuk lagi.

16) Meksiko

Meksiko mengatur mengenai Audit institution melalui konstitusi "Mexico's Constitution of 1917 with Amendments through 2015" yang diberi nama the federal auditing office. Organ audit tersebut memiliki wewenang khusus untuk memberlakukan hukum umum yang menetapkan dasar untuk koordinasi sistem antikorupsi nasional. Dalam hal pemilihan kepala dari the federal auditing office diatur pada article 79. Kepala dari the federal auditing office ditunjuk oleh dua pertiga dari anggota hadir di DPR, dengan masa kepemimpinan selama 8 tahun dan dapat diangkat kembali oleh DPR hanya sekali. Pemberhentian juga dilakukan oleh DPR dengan dua pertiga anggota hadir di DPR apabila terbukti melakukan pelanggaran hukum serius.

\section{7) Tunisia}

Tunisia's Constitution Amendment of 2014 mengatur mengenai Audit institution di Tunisia yang merupakan bagian dari financial judiciary yang diberi nama pengadilan audit. Pengadilan audit di Tunisia inilah yang menjalankan fungsi audit institution dengan wewenang mengawasi pengelolaan dana publik yang sehat sesuai dengan prinsipprinsip legalitas, efisiensi dan transparansi. Selain itu, pengadilan audit kekuasaan legislatif dan eksekutif dalam mengawasi pelaksanaan Hukum Keuangan dan penutupan anggaran. Sebagaimana ketentuan mengenai financial judiciary dan pengadilan audit diatur dalam konstitusi Tunisia article 117.
Pengadilan audit dipimpin oleh para hakim, pengaturan mengenai pemilihan hakim-hakim pengadilan audit ini terdapat pada ketentuan Article 106. Dalam pemilihan hakim-hakim tersebut, dilakukan melalui keputusan Presiden berdasarkan rekomendasi dewan yudisial tertinggi, sedangkan untuk hakim senior dipilih dan ditetapkan oleh Presiden melalui keputusan Presiden setelah berkonsultasi dengan kepala pemerintahan dan rekomendasi eksklusif dari dewan yudisial tertinggi.

18) Srilanka

Srilanka dalam konstitusinya, "The Constitution of The Democratic Socialist Republic Of Sri Lanka" mengatur mengenai Audit Service Commission yang dipimpin oleh seorang auditor general yang memiliki wewenang dalam hal mengaudit seluruh departemen, kantor sekretaris presiden, kantor sekretaris perdana menteri, kantor kabinet menteri-menteri, komisi pengadilan, pengadilan konstitusi, sekretaris jenderal parlemen, pemerintahan daerah, dan perusahaan negara. Dalam memimpin audit service commission seorang auditor general harus dipilih melalui persetujuan dari Constitutional Council dan ditetapkan oleh Presiden, sebagaimana disebutkan dalam article 153. Sedangkan, Pengangkatan dan pemberhentian seorang auditor general dilakukan oleh Presiden Srilanka.

19) Rusia

The Constitution Of The Russian Federation with Amendments mengatur audit institution Rusia yang bernama Accounts Chamber. Hal tersebut tertuang dalam article 101. Dalam menjalankan tugasnya Accounts Chamber dipimpin oleh deputy chairman dengan beberapa auditor di dalamnya, pemilihan Chairman, deputy chairman dan auditor dari accounts chamber menjadi kewenangan dewan federal dan house of representative (state duma). Kewenangan State duma diatur dalam article 102.

Adapun kewenangan State Duma dalam Pasal 103 adalah The jurisdiction of the House of Representatives [State Duma] includes the appointment and dismissal of the Chairman of the Accounting Chamber and half of its staff of auditors. Dengan demikian chairman dan 6 auditor lainnya dipilih oleh state duma. 
Walaupun konstitusi dan UU Federasi Rusia memberi kewenangan pemilihan dan penunjukkan kepada parlemen, namun dalam pelaksanaannya Parlemen meminta pertimbangan Presiden.

20) Polandia

Audit institution di Polandia bernama the supreme chamber of control yang dipimpin oleh President of the supreme chamber dan merupakan subordinate dari parlemen polandia. Pengaturan mengenai supreme chamber terdapat pada konstitusi Polandia article 202. Sedangkan, penentuan President supreme chamber dilakukan oleh parlemen Polandia (Sejm) dengan persetujuan senat dengan jangka waktu kepemimpinan presiden supreme chamber selama periode 6 tahun, sebagaimana diatur dalam artcile 205.

Dari Uraian 20 negara tersebut dapat terlihat bahwa model SAI yang dianut berbedabeda, ada yang menganut model westminster seperti Amerika, Afrika Selatan, Singapura, China,Vietnam, Kenya, Meksiko, Swedia dan Srilanka. Pada negara dengan tipe westminster, supreme audit institutionnya hanya dipimpin oleh 1 (satu) orang yang umum disebut dengan auditor general, namun dapat juga menggunakan istilah yang berbeda seperti di Amerika disebut comptroller general, China menyebut dengan istilah The Head of State Audit, dan lain-lain. Pada negara dengan tipe ini, secara konseptual sangat dimungkinkan general audit adalah pejabat parlemen karena pola kerja SAI sangat terikat dengan parlemen. Karakteristik lainnya adalah subyek pengaturan dalam konstitusi dan undangundang organik lebih condong mengatur hak, kewenangan, tugas dan fungsi terkait pengawsan keuangan kepada auditor general, dibanding pada lembaga audit nasionalnya.

Ada pula negara, yang menggunakan model pengadilan/judicial untuk supreme audit institution nya seperti Brazil, Portugal, Spanyol dan Tunisia. SAInya adalah pengadilan dan memiliki anggota yaitu para hakim. Yang kadang disebut juddge dalam konstitusi namun ada juga yang menggunakan istilah members saja atau sebutan yang lain. Sebutan untuk lembaga SAI sangat beragam seperti court of audit di Tunisia, audit

${ }^{18}$ Widhya Mahendra Putra, Analisis Kewenangan DPR Dalam Pemilihan Pimpinan BPK Guna Mewujudkan Kemandirian BPK (Studi Perbandingan Dengan tribunal of the union di Brazil dan lain-lain. SAI dengan model pengadilan ini juga umumnya masuk dalam lingkup kekuasaan yudikatif dan terpisah dari eksekutif maupun legislatif. Walaupun ada negara yang oleh konstitusinya, pengadilan audit dimasukkan dalam ruang lingkup pengaturan kewenangan legsilatif, seperti di Brazil. Model terakhir adalah negara-negara yang menggunakan model Board/Collegiate. Negara-negara tersebut antara lain Korea Selatan, Filipina, Mesir, Polandia, Rusia, Belanda dan Argentina termasuk juga Indonesia. Pada negara-negara ini umumnya institusi audit adalah bagian dari Parlemen.

Adapun hasil rekapitulasi mekanisme pemilihan pimpinan, anggota ataupun dewan dari masing-masing model adalah sebagai berikut:

Tabel Perbandingan Supreme audit institution ${ }^{18}$

\begin{tabular}{|c|c|c|c|c|c|c|}
\hline \multirow[t]{2}{*}{ No } & \multirow[t]{2}{*}{ Negara } & \multicolumn{3}{|c|}{$\begin{array}{c}\text { Lembaga yang terlibat } \\
\text { dalam pemilihan } \\
\text { Jabatan }\end{array}$} & \multirow[t]{2}{*}{ Bentuk } & \multirow[t]{2}{*}{ Keterangan } \\
\hline & & Pres & $\begin{array}{l}\text { Par/ } \\
\text { Leg }\end{array}$ & Lain & & \\
\hline 1 & Amerika & $\checkmark$ & $\checkmark$ & & $\begin{array}{c}\text { Westmins } \\
\text { ter }\end{array}$ & \\
\hline 2 & $\begin{array}{l}\text { Afrika } \\
\text { Selatan }\end{array}$ & $\checkmark$ & $\checkmark$ & & $\begin{array}{c}\text { Westmins } \\
\text { ter }\end{array}$ & \\
\hline 3 & $\begin{array}{l}\text { Singapur } \\
\text { a }\end{array}$ & $\checkmark$ & & $\checkmark$ & $\begin{array}{l}\text { Westmins } \\
\text { ter }\end{array}$ & $\begin{array}{l}\text { Presiden } \\
\text { dan } \\
\text { Perdana } \\
\text { Menteri }\end{array}$ \\
\hline 4 & RRC & $\checkmark$ & $\checkmark$ & & $\begin{array}{l}\text { Westmins } \\
\text { ter }\end{array}$ & $\begin{array}{l}\text { Usul prime, } \\
\text { angkat } \\
\text { presiden } \\
\text { dengan } \\
\text { persetujuan } \\
\text { kongres }\end{array}$ \\
\hline 5 & $\begin{array}{l}\text { Republik } \\
\text { Vietnam }\end{array}$ & & $\checkmark$ & & $\begin{array}{c}\text { Westmins } \\
\text { ter }\end{array}$ & \\
\hline 6 & Kenya & $\checkmark$ & $\checkmark$ & & $\begin{array}{c}\text { Westmins } \\
\text { ter }\end{array}$ & \\
\hline 7 & Meksiko & & $\checkmark$ & & $\begin{array}{c}\text { Westmins } \\
\text { ter }\end{array}$ & \\
\hline 8 & Swedia & & $\sqrt{ }$ & & $\begin{array}{l}\text { Westmins } \\
\text { ter }\end{array}$ & $\begin{array}{l}\text { dipilih oleh } \\
\text { parlemen } \\
\text { dari } \\
\text { anggotanya }\end{array}$ \\
\hline 9 & Srilanka & $\checkmark$ & & & $\begin{array}{c}\text { Westmins } \\
\text { ter }\end{array}$ & \\
\hline
\end{tabular}

Supreme Audit Institution Di Beberapa Negara) (Jakarta, 2018). 


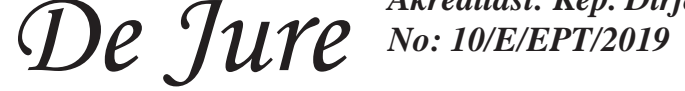

\begin{tabular}{|c|c|c|c|c|c|c|}
\hline \multirow[t]{2}{*}{ No } & \multirow[t]{2}{*}{ Negara } & \multicolumn{3}{|c|}{$\begin{array}{c}\text { Lembaga yang terlibat } \\
\text { dalam pemilihan } \\
\text { Jabatan }\end{array}$} & \multirow[t]{2}{*}{ Bentuk } & \multirow[t]{2}{*}{ Keterangan } \\
\hline & & Pres & $\begin{array}{l}\text { Par/ } \\
\text { Leg }\end{array}$ & Lain & & \\
\hline 10 & Brazil & $\checkmark$ & $\checkmark$ & & $\begin{array}{c}\text { Pengadila } \\
\mathrm{n}\end{array}$ & \\
\hline 11 & Tunisia & $\checkmark$ & & $\checkmark$ & $\begin{array}{c}\text { Pengadila } \\
\mathrm{n}\end{array}$ & $\begin{array}{l}\text { Presiden } \\
\text { dan } \\
\text { Supreme } \\
\text { Judisial } \\
\text { Council }\end{array}$ \\
\hline 12 & Portugal & $\checkmark$ & & & $\begin{array}{c}\text { Pengadila } \\
\mathrm{n}\end{array}$ & $\begin{array}{l}\text { Presiden } \\
\text { dan the } \\
\text { government } \\
\text { (yang } \\
\text { dikepalai } \\
\text { oleh } \\
\text { perdana } \\
\text { menteri) }\end{array}$ \\
\hline 13 & Spanyol & & $\checkmark$ & & $\begin{array}{c}\text { Pengadila } \\
\mathrm{n}\end{array}$ & $\begin{array}{l}\text { Pemilihan } \\
\text { anggota } \\
\text { dilakukan } \\
\text { oleh senat, } \\
\text { namun } \\
\text { khusus } \\
\text { untuk } \\
\text { penunjukka } \\
\text { n the } \\
\text { president of } \\
\text { the curt } \\
\text { oleh raja, } \\
\text { berdasar } \\
\text { usul } \\
\text { pengadilan } \\
\text { yang } \\
\text { berasal dari } \\
\text { para hakim } \\
\text { anggota } \\
\text { tersebut }\end{array}$ \\
\hline 14 & $\begin{array}{l}\text { Korea } \\
\text { Selatan } \\
\end{array}$ & $\checkmark$ & $\checkmark$ & & $\begin{array}{c}\text { Board/Co } \\
\text { llegiate }\end{array}$ & \\
\hline 15 & Filipina & $\checkmark$ & & $\checkmark$ & $\begin{array}{c}\text { Board/col } \\
\text { legiate }\end{array}$ & $\begin{array}{l}\text { Presiden } \\
\text { dan Komisi } \\
\text { Penunjukka } \\
\mathrm{n}\end{array}$ \\
\hline 16 & $\begin{array}{l}\text { Republik } \\
\text { Mesir }\end{array}$ & $\checkmark$ & $\checkmark$ & & $\begin{array}{c}\text { Board/col } \\
\text { legiate }\end{array}$ & \\
\hline 17 & Polandia & & $\checkmark$ & & $\begin{array}{c}\text { Board/col } \\
\text { legiate }\end{array}$ & \\
\hline 18 & Rusia & $\checkmark$ & $\checkmark$ & & $\begin{array}{c}\text { Board/col } \\
\text { legiate }\end{array}$ & $\begin{array}{l}\text { Parlemen } \\
\text { dan } \\
\text { President }\end{array}$ \\
\hline 19 & Belanda & & $\checkmark$ & $\checkmark$ & $\begin{array}{c}\text { Board/col } \\
\text { legiate }\end{array}$ & $\begin{array}{l}\text { Parlemen } \\
\text { dan } \\
\text { Governor }\end{array}$ \\
\hline 20 & $\begin{array}{l}\text { Argentin } \\
\mathrm{a}\end{array}$ & & $\checkmark$ & & $\begin{array}{c}\text { Board/col } \\
\text { legiate }\end{array}$ & \\
\hline
\end{tabular}

Apabila dijumlah secara keseluruhan dari 20 negara, 12 (duabelas) negara menggunakan metode pemilihan yang mengikutsertakan 2 lembaga dan 8 Negara menggunakan 1 (satu) lembaga, baik Presiden saja maupun legislatif saja. Pada negara dengan westminster model yang pola kerja bahkan auditornya merupakan pejabat parlemen menunjukkan hasil bahwa dari 9 (sembilan) negara, 5 (lima) negara menggunakan mekanisme pemilihan yang melibatkan 2 (dua) lembaga baik Presiden maupun Parlemen. NegaraNegara tersebut adalah Amerika, Afrika Selatan, Republik Rakyat China, Singapura dan Kenya. Kombinasi pembagian kewenangan dalam pemilihan diantara kedua negara dapat sangat beragam. Di Amerika pengusulan dilakukan oleh komisi yang dibentuk di Parlemen, dan Presiden berwenang menunjuk dari daftar rekomendasi yang diserahkan. Di Afrika Selatan, Presiden dengan persetujuan dari National Assembly. Di China, usulan berasal dari perdana menteri, diputuskan oleh Presiden dengan mendasarkan pada keputusan kongres dan komitenya. Sedangkan 5 negara lain, institusi yang melaksanakan pemilihan hanya 1 (satu) baik itu oleh Presiden saja atau oleh parlemen saja.

Adapun negara dengan model pengadilan, dari 4 (empat) negara, 2 (dua) negara menggunakan mekanisme pemilihan yaitu anggota court dipilih oleh 2 (dua) lembaga. Dua negara dimaksud adalah Brazil dan Tunisia. Mekanisme pemilihan di Brazil melibatkan Presiden dan Parlemen sedangkan di Tunisia pemilihan melibatkan Presiden dan Supreme Judicial Council. Sedangkan 2 (dua) Negara lainnya yakni Portugal dan Spanyol hanya mengikutsertakan 1 (satu) lembaga dalam mekanisme pemilihan. Di Portugal lembaga yang berwenang memilih adalah Presiden sedangkan di Spanyol lembaga yang berwenang adalah parlemen.

Pada negara dengan model board, yang secara teori berada di bawah parlemen justru menunjukkan hasil bahwa dari 7 (tujuh) negara, 5 (lima) negara menyelengarakan pemilihan anggota dewan tidak dilaksanakan sendiri oleh parlemen melainkan mengikutsertakan lembaga lain yakni Presiden untuk negara Korea Selatan, Republik Mesir, dan Rusia, Parlemen dan Governor untuk Belanda serta Parlemen dan Komisi Penunjuk untuk Filipina. Kombinasi pembagian kewenangan juga beragam seperti yang terjadi pada negara dengan model westminter. Beberapa contoh kombinasi pengaturan kewenangan antara lain: di Korea Selatan, Presiden berwenang menunjuk dengan mendasarkan persetujuan parlemen. Di Belanda, Parlemen berwenang mengusulkan nama, 
sedangkan penunjukkan diserahkan kepada Governor. Adapun di Filipina penunjukkan dilakukan oleh Presiden sedang komisi penunjuk hanya memberi rekomendasi. Sedangkan 2 (dua) negara lainnya hanya memberi kewenangan memilih pada 1 lembaga yakni parlemen.

Tabel dan uraian diatas menunjukkan bahwa pada negara yang sistem SAInya punya relasi erat dengan parlemen baik itu westminster model maupun board model, pemilihan pimpinan dan anggota dewan tidak lagi menjadi monopoli dari parlemen saja. Banyak negara yang juga memilih untuk mengikutsertakan lembaga lain.

\section{B. Konsep Pemilihan Pimpinan BPK Untuk Mewujudkan BPK yang Bebas dan Mandiri}

UUD NRI Tahun 1945 menetapkan bahwa Badan Pemeriksa Keuangan (BPK) merupakan lembaga yang mandiri. Sebagai supreme audit institution, BPK termasuk dalam jenis board/collegiate SAI karena dipimpin oleh dewan yang beranggotakan 9 (sembilan) orang, yang keanggotaannya diresmikan dengan Keputusan Presiden (Pasal 4 ayat (1), Undang-Undang No. 15 Tahun 2006 tentang Badan Pemeriksa Keuangan). Mekanisme pemilihan anggota BPK menggunakan mekanisme pemilihan oleh Parlemen dalam hal ini Dewan Perwakilan Rakyat yang mekanisme diatur dalam UUD NRI Tahun 1945, UU Nomor 17 Tahun 2014 tentang MPR, DPR dan DPD dan Peraturan DPR Nomor 1 Tahun 2014 tentang Tata Tertib. Dalam konstitusi, Pasal 23 F ayat (1) diatur bahwa Anggota Badan Pemeriksa Keuangan dipilih oleh Dewan Perwakilan Rakyat dengan memperhatikan pertimbangan Dewan Perwakilan Daerah dan diresmikan oleh Presiden. Pemilihan oleh parlemen ini secara teori memang menjadi salah satu ciri dari SAI dengan model board/collegiate. Lebih lanjut dalam UU Nomor 17 tahun 2014 dan Peraturan DPR Nomor 1 Tahun 2014, diatur bahwa mekanisme pemilihan anggota BPK adalah sebagai berikut:

1) Pemilihan anggota BPK dilakukan oleh DPR dengan memperhatikan pandangan DPD yang dalam hal ini dilaksanakan oleh Badan Musyawarah (Pasal 217 ayat (2) Peraturan DPR Nomor 1 Tahun 2014 tentang Tata Tertib).
2) Pimpinan DPR memberitahukan rencana pemilihan anggota BPK kepada pimpinan DPD dengan disertai dokumen kelengkapan persyaratan calon anggota BPK sebagai bahan DPD untuk memberikan pertimbangan.

3) Penyampaian pertimbangan DPD diberikan secara tertulis, tertutup, dan rahasia kepada pimpinan DPR (Pasal 208 ayat (2) Peraturan DPR Nomor 1 Tahun 2014 tentang Tata Tertib).

4) Hasil pemilihan anggota BPK oleh alat kelengkapan DPR dilaporkan dalam rapat paripurna DPR untuk ditetapkan dengan keputusan DPR dan selanjutnya diresmikan oleh Presiden (Pasal 192 ayat (4) UndangUndang No. 17 Tahun 2014 tentang Majelis Permusyawaratan Rakyat, Dewan Perwakilan Rakyat, dan Dewan Perwakilan Daerah).

Dari pengaturan ini terlihat bahwa mekanisme pemilihan BPK dilakukan oleh DPR dengan hanya meminta pertimbangan dari DPD.

Dalam pelaksanaannya, mekanisme pemilihan melalui fit dan proper test yang dijalankan oleh DPR tidaklah optimal. Bahkan cenderung menjadi mekanisme transaksi politik diantara anggota DPR dengan calon yang akan dipilih. Transaksi politik ini lebih dikenal dengan istilah politik dagang sapi (kohandel), politik dagang sapi ini baik mengenai orangnya (subjek), maupun kekuatan politiknya, yang juga terkait dengan politicking dimana ada upaya-upaya negatif dari para politisi di parlemen untuk mendukung calon yang dapat mengamankan perkara atau juga yang paling menguntungkan bagi partai ataupun politisi itu sendiri. ${ }^{19}$ Selain itu, alasan yang mendasari dipilihnya seorang calon, selain telah memenuhi syarat sebagaimana diatur dalam Pasal 13 UU Nomor 15 tahun 2006 tentang Badan Pemeriksa Keuangan, lebih condong pada pertimbangan yang sifatnya politis daripada pertimbangan yang didasari profesionalitas atau pengalaman dalam bekerja. Keadaan disebabkan mekanisme pemilihan oleh lembaga perwakilan lebih condong didasarkan pada popularity, acceptability, walaupun sebenarnya dalam konsep Sergivanni dan Corbally dua kriteria ini harus pula juga dilengkapi/disertai dengan dengan kriteria

\footnotetext{
${ }^{19}$ Mei Susanto, Rahayu Prasetianingsih, "Kekuasaan DPR Dalam Pengisian Pejabat Negara Dalam Sistem Ketatanegaraan Indonesia."
} 
De Jure

yang ketiga yaitu capability sehingga menghasilkan konsep disebut intergrated personality. Popularity atau popularitas, dimaksudkan sebagai penilaian apakah seseorang itu dikenal atau tidak dikenal dalam lingkungan anggota DPR. ${ }^{20}$ Dengan demikian dalam pemilihan anggota BPK, anggota DPR akan condong memilih calon yang dikenal olehnya. Sedangkan acceptability atau akseptabilitas, menunjuk pada kondisi penerimaan terhadap seseorang oleh masyarakat. Dalam konteks pemilihan atau rekruitmen yang dilakukan oleh DPR, penerimaan ini akan muncul bila ada kesesuaian kepentingan atau adanya kemampuan untuk menyuarakan kepentingan DPR. ${ }^{21}$

Sedangkan sebagai lembaga yang mandiri, BPK membutuhkan pimpinan yang juga mandiri dan tidak dapat diintervensi dalam mengambil sikap atau kebijakan yang diprediksinya dapat membawa kemaslahatan bagi tujuan yang sudah ditetapkan. Olehkarena itu perlu ada perbaikan pada mekanisme pemilihan anggota BPK. Dalam perspektif internasional, salah satu cara untuk menjamin kemandirian dari supreme Audit Institution dalam hal pemilihan dilakukan oleh Parlemen maka harus dipastikan bahwa proses pengangkatan anggota dewan bersifat transparan, politis netral dan menghasilkan pengangkatan orang-orang yang memiliki integritas. Hal ini sebagaimana dinyatakan dalam Making SAI independence a reality (some lesson from across the commonwealth) yaitu:

“... For most boards, the majority of the members would be non-executive members i.e. not employees of the SAI and therefore more likely to provide a constructive challenge to the Auditor General and the SAI's Leadership Team. If such a board is to be established, it is vital that the process of appointing board members is transparent, politically neutral and results in the appointment of people of integrity...".22

Dalam kaitannya dengan hasil perbandingan di subbab sebelumnya, untuk menyelesaikan persolan pemilihan BPK yang rawan menghilangkan independensi BPK kedepannya, Indonesia dapat mencoba menerapkan mekanisme

\footnotetext{
${ }^{20}$ Riyadi, "Peninjauan Ulang Kewenangan DPR Dalam Seleksi Pengisian Jabatan Publik."

${ }^{21}$ Ibid.
}

yang dijalankan di negara lain. Bisa mencontoh dari, 5 (lima) negara dari 20 negara dimaksud yang masuk dalam top ten leading SAIs. Negara tersebut antara lain Amerika Serikat, Brazil, Korea Selatan, Afrika Selatan dan Belanda. Kelima negara ini dalam pemilihannya mengikutsertakan dua lembaga yakni presiden dan parlemen/legislatif. Atau mengingat BPK termasuk dalam model board/collegiate maka dapat mengikuti tren mekanisme pemilihan di rumpun negara-negara dengan board sistem. Seperti telah disampaikan pada sub bab sebelumnya, dari 7 (tujuh) negara, 5 (lima) negara menyelengarakan pemilihan anggota dewan tidak dilaksanakan sendiri oleh parlemen melainkan mengikutsertakan lembaga lain yakni Presiden untuk negara Korea Selatan, Republik Mesir, dan Rusia, Parlemen dan Governor untuk Belanda serta Parlemen dan Komisi Penunjuk untuk Filipina. Namun demikian, jika akan tetap mempertahankan mekanism pemilihan oleh DPR dan DPD seperti saat ini maka perlu mencontoh praktik dinegara lain yang pemilihannya dilaksanakan hanya oleh parlemen namun tetap dapat menghasilkan pimpinan yang profesional. Salah satu negara yang dapat dicontoh adalah spanyol walaupun memang terdapat perbedaan antara BPK dan The Court of Account Spanyol karena bentuknya adalah pengadilan. Pemilihan 12 anggota The Court of Account dilaksanakan oleh Parlemen, enam Kongres Deputi dan enam oleh Senat. Jadi Kedudukan Deputi dan Senat di Spanyol sama-sama memilih, bukan dengan skema satu lembaga memilih dan lembaga yang lain memberi pertimbangan seperti yang diraktikkan pada mekanisme pemilihan di Indonesia. Selain itu, Spanyol juga mengatur bahwa salah satu syarat untuk menjadi anggota adalah memenuhi kualifikasi akademik dan latar belakang pendidikan yang menunjang.

Terkait dengan hal tersebut, kami menegaskan bahwa mekanisme pemilihan pimpinan SAI bukanlah satu-satunya tolak ukur keberhasilan yang mendasari penilaian kinerja SAI melainkan juga dipengaruhi faktor lain. Namun paling tidak dari prinsip mekanisme pemilihan pimpinan SAI, skema yang dipilih oleh negara tersebut telah mampu menciptakan

\footnotetext{
${ }^{22}$ Intosai, "No Title," last modified 2016, http://www.intosai.org/fileadmin/downloads/downloads/ 4_documents/Commonwealth_Making_SAI_independe nce_a_reality.pdf.
} 
pemimpin/anggota dewan yang mampu mengelola SAI secara baik dan mandiri. Kemampuan mengelola SAI dengan baik dan mandiri ini kemudian mampu meningkatkan performa SAI.

Dapat kita cermati bahwa keberadaan lembaga selain parlemen dapat membantu untuk memberi rekomendasi dengan mendasarkan pada pertimbangan yang sifatnya profesional sekaligus sebagai penyeimbang dalam pemilihan pimpinan/anggota. Selain itu, keterlibatan lembaga negara lain selain dari parlemen merupakan pelaksanaan dari proses berjalannya prinsip check and balances. Pada dasarnya prinsip check and balances dapat dioperasionalkan melalui cara-cara sebagai berikut. ${ }^{23}$

1) Pemberian kewenangan untuk melakukan tindakan kepada lebih dari satu lembaga. Misalnya kewenangan pembuatan undangundang diberikan kepada pemerintah dan parlemen;

2) Pemberian kewenangan pengangkatan pejabat tertentu kepada lebih dari satu lembaga, misalnya eksekutif dan legislatif;

3) Pengawasan langsung dari satu lembaga terhadap lembaga negara lainnya, seperti eksekutif diawasi oleh legislatif; dan

4) Pemberian kewenangan kepada pengadilan sebagai lembaga pemutus perkara sengketa kewenangan antara lembaga eksekutif dan legislatif.

Berdasarkan hasil perbandingan dan prinsip check and balances, pemilihan pimpinan BPK dapat dilakukan melalui keterlibatan lembaga negara lain misalnya Presiden, sehingga pemilihan yang dapat berjalan dilaksanakan secara netral dan bebas dari nilai politis karena faktor penentu terpilihnya calon anggota BPK tidak semata ada pada tangan Parlemen lagi Pelaksanaan check and balances dalam pemilihan anggota BPK juga akan mengurangi potensi penyalahgunaan kewenangan oleh Parlemen.

\footnotetext{
${ }^{23}$ Sunarto, "Prinsip Check and Balances Dalam Sistem Ketatanegaraan Republik Indonesia," Jurnal MasalahMasalah Hukum Vol. 45 No (2016): 160.
}

\section{KESIMPULAN}

Konsep pemilihan pimpinan/anggota Supreme audit institution di 20 Negara menunjukkan bahwa, secara garis besar mekanisme pemilihan terbagi menjadi 3 (tiga) yaitu: Pertama, pemilihan oleh 2 lembaga secara bersama dalam hal ini oleh parlemen dan Presiden atau Parlemen dengan lembaga lain diluar parlemen. Pada mekanisme ini intinya pemilihan tidak dilakukan secara sendiri oleh parlemen dan ada lembaga lagi yang berkedudukan sebagai penyeimbang. Jumlah negara yang menggunakan mekanisme ini adalah 12 (dua belas) negara. 10 (sepuluh) diantaranya adalah negara yang menganut model board/collegiate dan model westminster. Kedua model ini memiliki konsep dimana lembaga audit lebih condong menjadi bagian dari parlemen. Bahkan pada model board secara jelas dinyatakan INTOSAI, lembaga audit merupakan bagian dari parlemen sehingga umumnya pemilihan menjadi domain parlemen juga. Kombinasi pembagian kewenangan antara dua institusi ini dapat sangat beragam, parlemen dapat mengusulkan dan Presiden menyetujui seperti di Amerika Serikat, atau presiden menunjuk dengan persetujuan parlemen. Keutamaan dari mekanisme ini adalah kekuasaan menunjuk tidak terpusat pada satu lembaga, melainkan diimbangi oleh lembaga lain sehingga dapat menghindar terjadinya penyalahgunaan kewenangan. Mekanisme juga dapat dilaksanakan secara netral, anggota yang terpilih paling tidak bebas dari kepentingan politik yang dapat mempengaruhi performa dalam menjalankan tugas.

Kedua, pemilihan dilakukan hanya oleh Parlemen saja sebanyak 6 (enam) negara yaitu polandia dan argentina dari negara dengan model Board/Collegiate, Spanyol yang menggunakan model pengadilan, Meksiko, Vietnam serta Swedia dari negara dengan model westminster. Ketiga, pemilihan dilakukan hanya oleh Presiden saja sebanyak 3 (tiga) negara yaitu Singapura dan Srilanka dari negara dengan model westminster dan Portugal yang audits Institusinya berbentuk pengadilan.

Dari hasil perbandingan, 20 Negara dengan berbagai model SAI tersebut, bahkan 5 (lima) diantaranya yang menggunakan model pemilihan oleh 2 (dua) lembaga masuk dalam top ten leading 
SAIs. Negara tersebut antara lain Amerika Serikat, Brazil, Korea Selatan, Afrika Selatan dan Belanda. Sedangkan 2 negara lain yang masuk dalam top ten namun menggunakan 1 mekanisme pemilihan yakni Portugal yang pemilihan anggota courtnya diserahkan kepada Presiden dan Polandia yang menyerahkan pemilihan anggota dewan kepada parlemen. Selain itu, dapat dicermati bahwa keberadaan lembaga selain parlemen dapat membantu untuk memberi rekomendasi dengan mendasarkan pada pertimbangan yang sifatnya profesional sekaligus sebagai penyeimbang dalam pemilihan pimpinan/anggota.

Selain itu, keterlibatan lembaga negara lain selain dari parlemen merupakan pelaksanaan dari proses berjalannya prinsip check and balances. Dalam konteks pemilihan pimpinan BPK, dapat dilakukan melalui keterlibatan lembaga negara lain misalnya Presiden, sehingga pemilihan yang dapat berjalan dilaksanakan secara netral dan bebas dari nilai politis karena faktor penentu terpilihnya calon anggota BPK tidak semata ada pada tangan Parlemen lagi Pelaksanaan check and balances dalam pemilihan anggota BPK juga akan mengurangi potensi penyalahgunaan kewenangan oleh Parlemen.

\section{SARAN}

Mekanisme pemilihan pimpinan audit institution di beberapa negara memang terdiri dari beberapa variasi. Tidak sedikit pula, negara-negara yang mengadopsi sistem pemilihan head of audit institution dilakukan murni hanya oleh parlemen, salah satunya adalah Indonesia. Namun, dengan mekanisme seperti itu akan ada beberapa dampak negatif khususnya potensi adanya pengaruh secara politis dalam kinerja supreme audit institution. Yang mana kita ketahui bahwa supreme audit institution adalah lembaga audit independen suatu negara, sehingga sudah semestinya kinerja/dalam menjalankan tugas auditnya tidak akan di intervensi oleh kekuatan kekuasaan manapun kecuali hanya untuk menjalankan prinsip check and balances. Prinsip check and balances akan menghilangkan sifat superior dari suatu organ Negara. Hal ini disebabkan adanya pembatasan kekuasaan/kewenangan dari masing-masing organ negara. Dalam konteks Indonesia, mekanisme ini relevan digunakan khususnya dalam pemilihan ketua, anggota, pimpinan dari lembaga independen, termasuk Badan Pemeriksa Keuangan. Prinsip check and balances dilaksanakan dengan memberi peran kepada lembaga lain untuk ikut serta pada mekanisme pemilihan apabila memang diperlukan. Dari uraian tersebut kami menyarankan kepada pemangku kepentingan publik maupun legislator perundang-undangan untuk mengevaluasi dan mengkaji kembali mengenai mekanisme pengisian pimpinan BPK. Dalam pengisian jabatan publik/pimpinan BPK di Indonesia keterlibatan dua lembaga negara yaitu DPR dan Presiden cukup diperlukan sehingga mekanisme/prinsip check and balances antar organ negara dapat berjalan dengan baik, serta meminimalisir hal-hal negatif yang akan berpengaruh terhadap independensi BPK. Selain itu, konsep pemilihan pimpinan BPK dapat mengadopsi konsep negara lain yang menggunakan komisi tertentu sebagai penyeimbang. Komisi ini bertugas untuk memberikan usulan yang proses penyusunan daftar usulan ini dilakukan dengan mekanisme yang profesional. Hal ini seperti yang dilakukan oleh Korea Selatan, Mesir. Mekanisme selanjutnya DPR dapat menetapkan dengan persetujuan presiden atau sebaliknya, sehingga konsep pemilihan pimpinan BPK tidak terlihat di dominasi oleh salah satu lembaga negara seperti saat ini.

\section{UCAPAN TERIMA KASIH}

Pertama dan paling utama terucap rasa syukur kepada Allah SWT atas rahmat dan ridhoNya sehingga naskah jurnal ini dapat diselesaikan, serta shalawat beriring salam semoga tercurah kepada junjungan nabi besar Muhammad SAW, semoga tulisan jurnal ini bermanfaat dan dapat menjadi amal jariyah bagi penulis. Aamiin.

Terima kasih sebesar-besarnya kepada Ibunda yang senantiasa doa-doanya menembus pintu langit untuk kebaikan putranya, kepada Istri yang selalu memberikan sokongan doa, semangat, dan cinta, serta anak-anak yang memberikan energi dorongan untuk selalu bekerja dan berkarya. Kepada rekan-rekan MHTN Universitas Indonesia Tahun 2018 yang membersamai penulis dan tidak segan-segan memberikan koreksi dan masukan dalam setiap pengerjaan tugas dan penulisan artikel hukum, diucapkan terima kasih yang tak terhingga. Kepada para dosen-dosen pascasarjana UI khususnya Bapak Fitra Arsil, atas tugas yang bapak berikan memberikan kesempatan kepada saya untuk mengembangkan menjadi tulisan jurnal, diucapkan pula terima kasih. 
Teruntuk Dewan Editor, Reviewer dan seluruh jajaran staf jurnal penelitian hukum De Jure Balitbang Hukum dan HAM Kemenkumham RI, diucapkan terima kasih dan penghargaan yang tak terhingga karena telah berkenan mempublish naskah jurnal yang penulis kirimkan.

Akhir kata, penulis meyakini tulisan ini jauh dari sempurna, untuk itu penulis akan menerima saran dan kritik yang membangun demi perbaikan di kemudian hari.

\section{DAFTAR KEPUSTAKAAN}

Act 98/97 on Organisation and Procedural Law of the Court of Auditors (Republic of Argentina).

Act Consolidation of Consolidating Act No. 3 of 7 January 1997 as amended by Act No. 590 of 13 June 2006 as amended by Act No. 1272 of 21 December 2011 (Sweden).

Asshidiqie, Jimly. Konstitusi Ekonomi. Jakarta: Kompas, 2010.

Bank, World. "Features and Functions of Supreme Audit Institutions." Premnotes Public Sector 59 (2001).

China (People's Republic of)'s Constitution of 1982 with Amendments through 2004.

Egypt's Constitution of 2014.

GAO act tahun 1980 (United States of America).

Hendra Nurtjahjo. Lembaga, Badan, Dan Komisi Negara Independen (State Auxiliary Agencies) Di Indonesia: Tinjauan Hukum Tata Negara. Jakarta, 2005.

Intosai. "No Title." Last modified 2016. http://www.intosai.org/fileadmin/downloads/ downloads/4_documents/Commonwealth_M aking_SAI_independence_a_reality.pdf.

Law 2/1982 Organic Court of Audit (Spain).

Madril, Oce. "Pemilihan Anggota Badan Pemeriksa Keuangan.” Koran Tempo, 2013.

Mei Susanto, Rahayu Prasetianingsih, Lailani Sungkar. "Kekuasaan DPR Dalam Pengisian Pejabat Negara Dalam Sistem Ketatanegaraan Indonesia." Jurnal De jure Kemenkumham 18 Nomor 1 (2018).

Mexico's Constitution of 1917 with Amendments through 2015.
Peraturan DPR No. 1 Tahun 2014 tentang Tata Tertib. Republik Indonesia, 2014.

Putra, Widhya Mahendra. Analisis Kewenangan DPR Dalam Pemilihan Pimpinan BPK Guna Mewujudkan Kemandirian BPK (Studi Perbandingan Dengan Supreme Audit Institution Di Beberapa Negara). Jakarta, 2018.

Riyadi, Mochamad Taufik. "Peninjauan Ulang Kewenangan DPR Dalam Seleksi Pengisian Jabatan Publik,” 2015.

Simanjuntak, Dumaria. "Pengisian Jabatan Anggota Badan Pemeriksa Keuangan (BPK) Untuk Mewujudkan BPK Yang Independen.” Jurnal Hukum dan Pembangunan Tahun ke 4747 No. 2 (2017).

Soekanto, Soerjono. Pengantar Penelitian Hukum. Cetakan.3. Jakarta: UI Press, 1986.

Sunarto. "Prinsip Check and Balances Dalam Sistem Ketatanegaraan Republik Indonesia." Jurnal Masalah-Masalah Hukum Vol. 45 No (2016): 160.

The 1987 Constitution of The Republic of The Philippines, 1987

The Constitution of Argentina.

The Constitution of Brazil.

The Constitution of Kenya, 2010.

The Constitution of Netherland.

The Constitution of Polandia.

The Constitution of Singapore.

The Constitution of South Korea.

The Constitution of The Democratic Socialist Republic Of Sri Lanka.

The Constitution Of The Russian Federation with Amendments.

Final Constitution of the Republic of Vietnam

Tunisia's Constitution Amendment of 2014.

Undang-Undang Dasar Negara Republik Indonesia 1945

Undang-Undang No. 23 Tahun 1999 Tentang Bank Indonesia. Republik Indonesia, 1999.

Undang-Undang No. 17 Tentang MPR, DPR dan DPD Tahun 2014. Republik Indonesia, 2014

Undang-Undang No. 23 Tahun 1999 Tentang Bank 
Indonesia, 1999.

"Badan Pemeriksa Keuangan.” Last modified 2018. http://e-journal.uajy.ac.id/6942/3/ MIH201802.pdf, akses 3 Mei 2018.

"No Title." http://www.arsxm.org/EN/About/Organization/Do cuments/LandsverordeningAlgemeneRekenkamer_ EN_final_111111 comments JDM 201211.pdf, akses 12 November 2018. 